Borneo Journal of Sciences and Technology, Volume (1), Issue (1), Pages 53-61

DOI: https://doi.org/10.35370/bjost.2019.1.1-11

e-ISSN: 2672-7439

(C) 2018, UCTS Publisher.

Submitted: 21 November 2018

Accepted: 25 November 2018

Published: 31 January 2019

\title{
Properties of Composite Boards Properties from Elaeis guineensis Empty Fruit Bunch
}

\author{
${ }^{1}$ Razak Wahab, ${ }^{1}$ Mohamad Saiful Sulaiman ${ }^{1},{ }^{1}$ Ros Syazmini Mohd Ghani, ${ }^{1}$ Nasihah Mokhtar, \\ ${ }^{2}$ Siti Marlia Mohd Don and ${ }^{3}$ Hashim W. Samsi \\ ${ }^{1}$ University College of Technology Sarawak (UCTS), 96000 Sibu, Sarawak, Malaysia \\ ${ }^{2}$ Universiti Malaysia Kelantan (UMK), 17600 Jeli, Kelantan, Malaysia \\ ${ }^{3}$ Forest Research Institute Malaysia (FRIM), 52109 Kuala Lumpur, Malaysia
}

\begin{abstract}
This study focussed on composite boards made from Elaeis guineesis empty fruit bunches (EFB). The EFB supplied by a smallholder oil palm planter in Kuala Krai, Kelantan. The fibre cutter and crusher were used in turning the EFB into smaller size particles. They were screened with four-tier sieve shaker used to remove the oversize particles and impurities present. Hardeners and wax added during the mixing process at $1 \%$ and $3 \%$. Boards of three (3) different densities were produced using urea-formaldehyde as the bonding agent. The boards produced later conditioned in a chamber set at $20 \pm 2^{\circ} \mathrm{C}$ and $65 \%$ relative humidity. The testing procedure set by EN Standards and specifications were followed. The tests results showed the EFB composite boards possessed excellent physical and mechanical properties. The MOR, MOE and internal bonding of the boards were $22.91 \mathrm{~N} / \mathrm{mm}^{2}, 2059.56 \mathrm{~N} / \mathrm{mm}^{2}$, and $0.98 \mathrm{~N} / \mathrm{mm}^{2}$. The internal bonding for both edge and face screw withdrawal were $467.47 \mathrm{~N} / \mathrm{mm}^{2}$, and 512.37 $\mathrm{N} / \mathrm{mm}^{2}$ respectively. Boards with $700 \mathrm{~g} / \mathrm{cm}^{3}$ density and $14 \%$ resin content met all the requirement needed according to standard exercised. Scanning electron microscope images of low-performance boards showed the resin and fibre in the board interacted closely, but voids appeared at the cross-section suggesting moisture penetrated the board via the open spaces and attacked the linkages existed, thus cause the board to have a low property. The thermal stability of the boards manufactured studied using the Thermogravimetric Analysis.
\end{abstract}

Keywords: Empty fruit bunch, composite boards, physical and mechanical strength, thermogravimetric analysis.

\section{INTRODUCTION}

Wood products such as large timbers or lumber commonly used in solid forms. However, due to rapid deforestation, the ever-increasing demand and increases in pricing make the application of solid wood no longer possible. The new composite product started with the glued laminated beams from thick laminates, plywood from veneers, strand board from strands, flakeboard from flakes, particleboard from particles and fiberboard from fibres, has become popular due to the scarcity in obtaining wood supply [1][2].

Oil palm is the largest and essential plantation crop in Malaysia. The oil palm trees generally could last between 25-30 years before the next replantation needs to be done. With this replantation cycle, the huge amount of available biomass is available and not being fully utilized and normally left to rot naturally. Research has been conducted in determining the most suitable part of the oil palm biomass that can produce renewable lignocelluloses material for the bio- composite industry. Empty fruit bunch (EFB) is one of the oil palm biomass materials that are found in abundance in Malaysia. The moisture content of fresh EFB is very high, about over $60 \%$ on a wet EFB basis. It is a poor fuel without drying and presents a considerable emission problem such that its burning is discouraged. Palm oil mills normally use the shells and drier part of the natural fibre to produce steam to fuel their boilers [3]. As EFB is readily available and abundance in Malaysia, The EFB available on the average of 12.4 million ton/year from the plantations and oil palm mills can be converting into composite boards to resolve the scarcity of wood sources [4].

The current studies focus on properties of composite boards made from EFB of oil palm trees. The objectives of the studies were to determine and study (i) the physical and mechanical properties, (ii) the bonding properties of the EFB composite boards, and (iii) the thermal properties, of the particle board made from EFB. 


\section{MATERIALS AND METHODS}

The EFB samples were supplied by a smallholder oil palm planter in Kuala Krai, Kelantan. The fibre cutter and crusher were used in turning the EFB into smaller sizes. They were screened with four-tier sieve shaker used to remove the oversize and impurities present. The particles that passed through a $2.0 \mathrm{~mm}$ sieve size and retained at $1.5 \mathrm{~mm}$ sieve size were used in this study. The particles were then oven-dried at $103 \pm 2^{\circ} \mathrm{C}$ for 24 hrs. The mass of the particles was measured to obtain targeted densities of 500,600 and $700 \mathrm{~kg} / \mathrm{m}^{3}$. They were mixed with UF resin at three (3) levels of resin content; $10 \%, 12 \%$, and $14 \%$ level. The mixed particles were hand-felted into a wooden frame $340 \mathrm{~mm}$ x 340 $\mathrm{mm}$ size of a caul plate. The formed mats were cols prepressed. The forming frame removed leaving the mat on the caul plate. The mats then pressed under a hotpress machine at temperature $165^{\circ} \mathrm{C}$ for 6 minutes. The boards produced were then cooled and cut into standard testing size. The testing samples were stored in a conditioning chamber conditioned at $20 \pm 2^{\circ} \mathrm{C}$ and $65 \%$ relative humidity until reaching their constant weight, before the testing procedure. All boards were produced in accordance EN Standard 1993 [5].

\section{Physical Studies}

The physical properties studies such as the density moisture content, water absorption and the 2 and 24 hours elapsed thickness swelling tests of the EFB composite boards. All studies were conducted by Standard EN 322: 1993 [6], Standard EN 223: 1993 [7] and Standard EN 317: 1993 [8].

\section{Mechanical Studies}

The determination of the mechanical studies carried out includes the static bending test for the MOR and MOE, internal bonding tests and screw withdrawal tests for the edge and the face. All the tests were done by using Universal Testing Machine in according to the Standards EN 310: 1993 [5] and EN 325: 2012 [9]. Screw hold strength of the EFB boards was tested according to Standard BS 5669: 1989 [11].

\section{Scanning Electron Microscopy}

The Scanning Electron Microscope located in FRIM was used in studying the structure of the EFB boards to determine the interaction between resin UF and EFB particles. Clean cut samples of size $1 \mathrm{~cm}$ x $1 \mathrm{~cm}$ x $1 \mathrm{~cm}$ were used. The SEM equipment is connected to a computer for image storage and processing.

\section{Thermogravimetric Analysis (TGA)}

The thermogravimetric analysis was used to measure the thermal stability of the EFB boards. Thermal analysis was carried out with a computerized TA Instrument SDT-Q600 thermogravimetric analyzer. Samples $(5.5 \pm 0.2 \mathrm{mg})$ were placed in alumina crucibles. TGA was performed under $100 \mathrm{ml} \mathrm{min}^{-1}$ nitrogen with a heating rate of $10^{\circ} \mathrm{C} / \mathrm{min}$. The weight change with temperature was measured and used to infer the moments of change during the heating. The temperature at which the rate of maximum degradation occurs was taken as an indicator of the stability to the material in comparative studies [12].

\section{RESULTS AND DISCUSSION}

\section{Physical Properties}

Table 1 shows the The moisture content and thickness swelling (TS) at different density and resin content for 2 and 24 hours time elapsed of EFB composite boards. The targetted boards of $500 \mathrm{~kg} / \mathrm{m}^{3}$ with $10 \%, 12$ and $14 \%$ resin contents possessed density of $506.29 \mathrm{~kg} / \mathrm{m}^{3}$, $506.90 \mathrm{~kg} / \mathrm{m}^{3}$ and $517.60 \mathrm{~kg} / \mathrm{m}^{3}$ respectively. Targetted board $600 \mathrm{~kg} / \mathrm{cm} 3$ with $10 \%, 12 \%$ and $14 \%$ resin contents possessed density of $598.65 \mathrm{~kg} / \mathrm{cm}^{3}, 608.90$ $\mathrm{kg} / \mathrm{cm}^{3}$ and $620.05 \mathrm{~kg} / \mathrm{cm}^{3}$. Targetted boards of 700 $\mathrm{kg} / \mathrm{cm}^{3}$ having actual densities of $704.03 \mathrm{~kg} / \mathrm{cm}^{3}$, $714.72 \mathrm{~kg} / \mathrm{cm}^{3}$ and $723.89 \mathrm{~kg} / \mathrm{cm}^{3}$ for $10 \%, 12 \%$ and $14 \%$ resin contents.

The MC values were $6.64 \%$ for the $10 \%$ resin content, $6.72 \%$ for the $12 \%$ resin content and $7.12 \%$ for the $14 \%$ resin content. The $500 \mathrm{~kg} / \mathrm{cm}^{3}$ density boards possessed MC value of $6.89 \%, 7.15 \%$ and $8.48 \%$ for $10 \%, 12 \%$ and $14 \%$ resin contents respectively. Boards of $600 \mathrm{~kg} / \mathrm{m}^{3}$ have MC of $6.04 \%$ for $10 \%$ resin content, $6.83 \%$ for $12 \%$ resin content and $6.48 \%$ for $14 \%$ resin content.

The EFB boards of targetted densities 500, 600 and $700 \mathrm{~kg} / \mathrm{cm}^{3}$ possessed a particular trend at the 2 and 24-hours thickness swelling where the rate of the board swelled decreased as the amount of resin applied increased. The $500 \mathrm{~kg} / \mathrm{cm}^{3}$ density boards with $10 \%$ resin content $10 \%$ possess high rate of thickness swelling at $35.10 \%$ for the 2-hours time elapsed. Low value at $16.34 \%$ obtained for the 2-hours thickness swelling for boards with $700 \mathrm{~kg} / \mathrm{m}^{3}$ density with resin content $14 \%$. The highest value of $41.11 \%$ obtained for 24-hours time elapsed in the thickness swelling for the boards of $500 \mathrm{~kg} / \mathrm{m}^{3}$ with resin content $10 \%$. Boards at density $700 \mathrm{~kg} / \mathrm{cm}^{3}$ with $14 \%$ resin content $14 \%$ possessed the lowest thickness swelling at $12.99 \%$ for the 24-hour elapse time.

Chemical components in the resin applied capable of cross-linking with the hydroxyl group in the 
boards fibre. This reduced the hygroscopicity level of the boards. The monomer, the polymerisation rates, the cross-linking and pore-size of the polymer network, the bond strength, the interaction between polymer and water, the filler and the resin-filler interface may affect the hygroscopic expansion [13]. The existence of the void found in low-density EFB boards may provide spaces that enhance high water absorption [14]. The high porous structure of the board allows penetration of water into the board and increases water uptake causes the board to swell and causes a rise of thickness swelling [15].

Table 2 shows the water absorption of EFB boards at different density and resin content. The EFB boards at densities of 500,600 and $700 \mathrm{~kg} / \mathrm{m}^{3}$ possessed the same trend for both the 2-, and 24-hours elapse. The rate of the water absorbed board absorbed decreases as the amount of resin applied increases.

Table 1: The moisture content and thickness swelling (TS) at different density and resin content for 2- and 24-hours time elapsed of EFB composite boards

\begin{tabular}{cccccc}
\hline $\begin{array}{c}\text { Board density } \\
\left(\mathrm{kg} / \mathrm{m}^{3}\right)\end{array}$ & $\begin{array}{c}\text { Resin content } \\
(\%)\end{array}$ & $\begin{array}{c}\text { Moisture } \\
\text { content }(\%)\end{array}$ & Density $\left(\mathrm{kg} / \mathrm{m}^{3}\right)$ & \multicolumn{2}{c}{ TS $(\%)$} \\
\hline 500 & 10 & $6.89(0.42)$ & $506.29(31.27)$ & $35.10(2.75)$ & $41.11(2.86)$ \\
& 12 & $7.15(0.43)$ & $506.90(25.54)$ & $26.44(3.42)$ & $38.25(2.61)$ \\
& 14 & $8.48(0.26)$ & $517.60(14.25)$ & $24.90(0.63)$ & $26.69(1.18)$ \\
\hline 600 & 10 & $6.04(0.72)$ & $598.65(14.43)$ & $24.04(2.56)$ & $25.46(1.50)$ \\
& 12 & $6.83(0.81)$ & $608.90(27.31)$ & $23.01(0.68)$ & $24.41(1.84)$ \\
& 14 & $6.48(1.16)$ & $620.05(25.19)$ & $20.90(1.73)$ & $21.41(2.78)$ \\
\hline 700 & 10 & $6.64(0.29)$ & $704.03(31.91)$ & $19.18(0.43)$ & $21.37(0.54)$ \\
& 12 & $6.72(0.46)$ & $714.72(7.21)$ & $17.46(1.20)$ & $16.88(0.43)$ \\
& 14 & $7.12(0.30)$ & $723.89(17.47)$ & $16.34(0.19)$ & $12.99(2.50)$ \\
\hline
\end{tabular}

Table 2: The water absorption (WA) at different density and resin contents for 2- and 24-hours time elapsed of EFB composite boards

\begin{tabular}{cccc}
\hline \multirow{2}{*}{$\begin{array}{c}\text { Board density } \\
(\mathrm{kg} / \mathrm{cm} 3)\end{array}$} & $\begin{array}{c}\text { Resin content } \\
(\%)\end{array}$ & Two h & $24 \mathrm{~h}$ \\
\cline { 3 - 4 } & 10 & $139.02(5.71)$ & $206.77(10.71)$ \\
& 12 & $119.20(3.06)$ & $140.81(3.93)$ \\
& 14 & $113.26(7.59)$ & $138.29(2.55)$ \\
\hline 600 & 10 & $92.50(7.38)$ & $127.48(6.16)$ \\
& 12 & $82.78(5.95)$ & $108.58(2.05)$ \\
& 14 & $79.84(5.23)$ & $96.95(3.45)$ \\
\hline 700 & 10 & $64.24(3.32)$ & $91.22(2.56)$ \\
& 12 & $44.27(3.09)$ & $69.12(5.24)$ \\
& 14 & $40.71(3.75)$ & $59.62(3.71)$ \\
\hline
\end{tabular}

Boards of density $500 \mathrm{~kg} / \mathrm{m}^{3}$ with resin content $10 \%$ possess a higher rate of $139.02 \%$ in the 2 -hours water absorption. The lowest of $40.71 \%$ recorded by the $700 \mathrm{~kg} / \mathrm{m}^{3}$ density board at resin content $14 \%$. The absorption rate of $206.77 \%$ in 24 -hours attained by the board $500 \mathrm{~kg} / \mathrm{m}^{3}$ density with $10 \%$ resin content. The lowest value of $59.62 \%$ in 24-hours water absorption recorded by board $700 \mathrm{~kg} / \mathrm{m}^{3}$ of resin $14 \%$. The increase in EFB boards density enhanced the thickness swelling and decreases water absorption [16]. More water absorption occurred in high density boards compared to the those with low density. The adhesion strength of the board decreases once dwell inside the water increases,. The increment in the adhesion ratio resulted in low thickness swelling and water absorption as the high adhesive ratio equals more adhesive amount applied, resulting in enhances the resin bonding strength of the materials.

The trends of the boards in swelling remained deficient even after the increases in the density of the EFB boards and the doses of adhesive [17]. Increasing in density of the boards significantly improved mechanical properties and water resistance of the boards [18]. The higher density boards had a large contact surface area between particles, making the adhesive function more effectively, as compared to the

lower density particle board (Zheng et al., [18]. Highdensity boards with less void volume result in better 
water resistance. A similar finding also recorded by Izyan et al., [19].

\section{Mechanical Properties}

The procedure for mechanical testing was executed as outlined in Standards EN 310: 1993 [5] and EN 325: 2012 [9]. The MOR indicates the ability of a specimen to withstand transverse (bending) forces perpendicular to its longitudinal axis [20]. The testing conducted using the universal testing machine, where the samples of the EFB boards placed flat on the supports as the load applied. Results of MOR obtained were compared with rubberwood. Table 3 presents MOR of the EFB boards at various densities. The resistance to rupture increases with the increasing in the density of the board and resin content. Board with density $700 \mathrm{~kg} / \mathrm{m}^{3}$ with $14 \%$ resin content recorded the highest MOR value of $22.91 \mathrm{~N} / \mathrm{mm}^{2}$ followed by the board made with resin content $12 \%$ at $18.97 \mathrm{~N} / \mathrm{mm}^{2}$ with the same density. The low value of MOR at $6.37 \mathrm{~N} / \mathrm{mm}^{2}$ recorded attained by the $500 \mathrm{~kg} / \mathrm{m}^{3}$ with $10 \%$ resin content followed by $12 \%$ and $14 \%$ resin content at 6.75 $\mathrm{N} / \mathrm{mm}^{2}$. The boards at density $600 \mathrm{~kg} / \mathrm{m}^{3}$ showed an increasing trend from $10 \%$ at $10.20 \mathrm{~N} / \mathrm{mm}^{2}$ to $12 \%$ at
$10.26 \mathrm{~N} / \mathrm{mm}^{2}$ and $14 \%$ at $12.77 \mathrm{~N} / \mathrm{mm}^{2}$ resin content respectively. The minimum requirement for MOR at $14.0 \mathrm{~N} / \mathrm{mm}^{2}$ for general uses type of board according to Standard EN 312-3 [21] were attained for the EFB boards with $700 \mathrm{~kg} / \mathrm{cm}^{3}$ density with 12 and $14 \%$ resin contents. Compared with composite boards the from rubberwood [22], the MOR value of EFB boards ranged from 22.91 to $22.8 \mathrm{~N} / \mathrm{mm}^{2}$.

High stiffness properties normally resulted in higher MOE values. Boards with low MOE tend to be ductile or flexible and brittle when the MOE value is high [23][24]. Testing for MOE analysis was done using the universal testing machine. The results on MOE tested of the EFB boards were presented in Table 3. High MOE recorded for boards with $700 \mathrm{~kg} / \mathrm{m}^{3}$ density with $14 \%$ resin content at $2059.56 \mathrm{~N} / \mathrm{mm}^{2}$, followed at $1683.93 \mathrm{~N} / \mathrm{mm}^{2}$ and $1063.43 \mathrm{~N} / \mathrm{mm}^{2}$ by boards with $12 \%$ and $10 \%$ resin contents respectively. Boards at a density at $500 \mathrm{~kg} / \mathrm{cm}^{3}$ with $10 \%$ resin content possessed low value MOE at $385.64 \mathrm{~N} / \mathrm{mm}^{2}$ followed by $419.43 \mathrm{~N} / \mathrm{mm}^{2}$ and $447.44 \mathrm{~N} / \mathrm{mm}^{2}$ at $10 \%$, $12 \%$ and $14 \%$ resin contents. The MOE of board at density $600 \mathrm{~kg} / \mathrm{m}^{3}$ increases from $673.82 \mathrm{~N} / \mathrm{mm}^{2}$ to $773.37 \mathrm{~N} / \mathrm{mm}^{2}$ and $1006.78 \mathrm{~N} / \mathrm{mm}^{2}$ with resin at $10 \%$, $12 \%$ and $14 \%$ respectively.

Table 3: The modulus of rupture (MOR) and modulus of elasticity (MOE) at different density and the resin content of EFB composite boards

\begin{tabular}{|c|c|c|c|}
\hline Board density (kg/m3) & Resin content $(\%)$ & MOR (N/mm2) & MOE (N/mm2) \\
\hline \multirow[t]{3}{*}{500} & 10 & $6.07(1.54)$ & $385.64(108.02)$ \\
\hline & 12 & $6.37(0.88)$ & $419.43(88.55)$ \\
\hline & 14 & $6.75(1.47)$ & $447.44(134.29)$ \\
\hline \multirow[t]{3}{*}{600} & 10 & $10.20(0.79)$ & $673.82(55.64)$ \\
\hline & 12 & $10.26(3.07)$ & $773.37(156.73)$ \\
\hline & 14 & $12.77(3.37)$ & $1006.78(231.94)$ \\
\hline \multirow[t]{3}{*}{700} & 10 & $11.03(3.33)$ & $1063.43(348.71)$ \\
\hline & 12 & $18.97(3.09)$ & $1683.93(255.10)$ \\
\hline & 14 & $22.91(3.81)$ & $2059.56(285.01)$ \\
\hline EN 312-3 & & 14.0 & 1800 \\
\hline Rubberwood & & $22.8 *$ & $2381 *$ \\
\hline
\end{tabular}

* Paridah et al., 2010

The $700 \mathrm{~kg} / \mathrm{m}^{3}$ density EFB composite boards with MOE $1800 \mathrm{~N} / \mathrm{mm}^{2}$ at $14 \%$ resin content not only met the minimum requirement but exceeded the required values for general uses type of board [21]. The maximum MOE at $2059.56 \mathrm{~N} / \mathrm{mm}^{2}$ obtained for the EFB boards was slightly lower than MOE of rubberwood $\left(2381 \mathrm{~N} / \mathrm{mm}^{2}\right)$.

High IB value at $0.98 \mathrm{~N} / \mathrm{mm}^{2}$ followed by IB at $0.77 \mathrm{~N} / \mathrm{mm}^{2}$ with $12 \%$ resin content of the same board density (see Table 7) obtained that the EFB boards 700 $\mathrm{kg} / \mathrm{m}^{3}$ with $14 \%$ resin content. Low in IB recorded for boards at $500 \mathrm{~kg} / \mathrm{m}^{3}, 0.18 \mathrm{~N} / \mathrm{mm}^{2}, 0.19 \mathrm{~N} / \mathrm{mm}^{2}$ and 0.23 $\mathrm{N} / \mathrm{mm}^{2}$ at $10 \%, 12 \%$ and $14 \%$ resin contents respectively. IB value of boards at density $600 \mathrm{~kg} / \mathrm{m}^{3}$ increase from $0.28 \mathrm{~N} / \mathrm{mm} 2, \quad 0.31 \mathrm{~N} / \mathrm{mm} 2$ and 0.36 $\mathrm{N} / \mathrm{mm}^{2}$ at $10 \%, 12 \%$ and $14 \%$ resin contents. The minimum requirement of $0.40 \mathrm{~N} / \mathrm{mm}^{2}$ for general type of boards were met by the EFB boards of $700 \mathrm{~kg} / \mathrm{m}^{3}$ density with all the $10 \%, 12 \%$ and $14 \%$ resin contents. The values were slightly lower than the rubberwood boards IB. These are expected as the EFB boards possessed more voids.. The voids directly caused inefficiency of the inter-fibre bonding [25]. For fine and mixed particles, the chance of tighter packing and closer contact between the particles is greater, which may positively contribute to the boards [26]. 
The platen temperature affects the internal bonding of the boards. The internal bonding in the UF resin boards improved significantly with the increase of the platen temperature. The high temperature of the platen promotes higher cross-linking and curing of the resin. During the pressing process, the temperature remain low at a center of the boards compared with the surface. Correct platen temperature needed to be apply to ensure sufficiently high temperature at the core in allowing the resin to cure. Applying wax can lower internal bonding of the EFB boards due to the differences in chemical bonding between UF resin and particles. The wax interferes with UF resin when hydrogen bonds are formed [27].

The results of edge screw withdrawal on EFB composite boards highlighted in Table 4 presents the results of the edge screw withdrawal produced. High value of edge screw withdrawal recorded by the boards at $700 \mathrm{~kg} / \mathrm{m}^{3}$ at $467.47 \mathrm{~N} / \mathrm{mm}^{2} 440.67 \mathrm{~N} / \mathrm{mm}^{2}$ and $412.27 \mathrm{~N} / \mathrm{mm}^{2}$ with $14 \%, 12$ and $10 \%$ resin contents. Low value of edge screw withdrawal obtained from boards at $500 \mathrm{~kg} / \mathrm{m}^{3}$ at $168.18 \mathrm{~N} / \mathrm{mm}^{2}, 178.82 \mathrm{~N} / \mathrm{mm}^{2}$ and $189.93 \mathrm{~N} / \mathrm{mm}^{2}$ with $10 \%, 12$ and $14 \%$ resin contents respectively. The edge screw withdrawal value for boards at $600 \mathrm{~kg} / \mathrm{m}^{3}$ were $232.72 \mathrm{~N} / \mathrm{mm}^{2}, 239.08$ $\mathrm{N} / \mathrm{mm}^{2}$ and $302.13 \mathrm{~N} / \mathrm{mm}^{2}$ increases from $10 \%$ to $12 \%$ and $14 \%$ resin contents. The EFB boards with density $700 \mathrm{~kg} / \mathrm{cm}^{3}$ at $10 \%, 12 \%$ and $14 \%$ resin contents met the minimum requirement for edge screw withdrawal property according to BS 5669:1989 [11].

Results of the edge screw withdrawal tabulated in Table 4 presents face screw withdrawal of the EFB boards manufactured. The boards of $700 \mathrm{~kg} / \mathrm{cm} 3$ with $14 \%$ resin content gives the highest values at 512.37 $\mathrm{N} / \mathrm{mm}^{2}, 511.23 \mathrm{~N} / \mathrm{mm}^{2}$ and $459.72 \mathrm{~N} / \mathrm{mm}^{2}$ at $10 \%, 12 \%$ and $14 \%$ resin contents. The lowest value obtained by boards having a density of $500 \mathrm{~kg} / \mathrm{cm} 3$ with $10 \%$ $(193.42 \mathrm{~N} / \mathrm{mm} 2)$ resin content followed by $12 \%$ $\left(244.50 \mathrm{~N} / \mathrm{mm}^{2}\right)$ and $14 \%\left(268.38 \mathrm{~N} / \mathrm{mm}^{2}\right)$ resin contents of the same density boards. The face screw withdrawal of the boards with $600 \mathrm{~kg} / \mathrm{m}^{3}$ increases from the $10 \%\left(305.40 \mathrm{~N} / \mathrm{mm}^{2}\right)$ to $12 \%\left(314.60 \mathrm{~N} / \mathrm{mm}^{2}\right)$ and $14 \%\left(321.62 \mathrm{~N} / \mathrm{mm}^{2}\right)$ resin content. Higher particle loading tends to strengthen the boards with the increase in densities further assists the boards to hold the screw better [15][2].

Table 4: Internal bonding (IB) of EFB composite boards at different density and resin content.

\begin{tabular}{ccccc}
\hline Board density $\left(\mathrm{kg} / \mathrm{m}^{3}\right)$ & Resin content $(\%)$ & $\mathrm{IB}\left(\mathrm{N} / \mathrm{mm}^{2}\right)$ & $\mathrm{Swe}\left(\mathrm{N} / \mathrm{mm}^{2}\right)$ & $\mathrm{SWf}\left(\mathrm{N} / \mathrm{mm}^{2}\right)$ \\
\hline 500 & 10 & $0.18(0.04)$ & $168.18(23.56)$ & $193.42(29.58)$ \\
& 12 & $0.19(0.02)$ & $178.82(39.51)$ & $244.50(50.53)$ \\
& 14 & $0.23(0.03)$ & $189.93(20.05)$ & $268.38(48.04)$ \\
\hline 600 & 10 & $0.28(0.07)$ & $232.72(20.19)$ & $305.40(24.23)$ \\
& 12 & $0.31(0.08)$ & $239.08(25.01)$ & $314.60(34.51)$ \\
& 14 & $0.36(0.17)$ & $302.13(41.53)$ & $321.62(32.27)$ \\
\hline 700 & 10 & $0.54(0.06)$ & $412.27(38.10)$ & $459.72(42.45)$ \\
& 12 & $0.77(0.12)$ & $440.67(35.38)$ & $511.23(32.45)$ \\
\hline EN 312-3 & 14 & $0.98(0.08)$ & $467.47(46.18)$ & $512.37(87.26)$ \\
Rubberwood & & 0.40 & 360.0 &
\end{tabular}

*Paridah et al., 2010

\section{Microscopy Studies}

Samples from both EFB composite and UF resin boards were randomly selected for the microscopy studies. Observations of their structure especially the occurrence of the fibers compression, binder-fiber compatibility and void's occurrence were given preferences. The boards with $500 \mathrm{~kg} / \mathrm{m}^{3}$ density UF with $10 \%$ resin content level were selected for the micrographic studies. Figures 1 and 2 show the micrographs of the cross-section of EFB composite board with resin content level $10 \%$ at 100x and 500x magnification. The occurrence of fibers compression occurred in the EFB boards (Figure 1). The fibers compression most probably occurred during the pressing stage at different applied pressure and temperatures. The fibers in EFB boards were forced to shrink to a specified thickness resulted in the compressed structure of the fibres. This reduced in the lumen void spaces and increase the density of the board produced [28]. There is good compatibility between EFB fibre and UF resin in the particle board manufactured (see Figure. 2). The fibers touch one other closely, and no clumped observed in the UF resin boards. This affected the result on the mechanical properties especially on the MOR and MOE properties of the board [29]. The perpendicular applied load to the EFB board surface creates compression stress on the top side that transforms into tension stress in the bottom side of the EFB boards exceeding the middle portion. The load stresses transferred from one particle to another particle in the EFB fiber's that acts through a 
medium of the load transfer [22]. The existence of voids showed the existence of gaps occurred at certain parts on the EFB boards that lead to high water absorption. The voids created more parts of EFB fiber exposed to the surrounding moisture [13]. This can be minimized by using smaller sizes of particles in the manufactured boards [30].

\section{Thermal Properties}

Computerised TA Instruments SDT-Q600 TGA was used in analysing the thermal properties of the EFB composite boards. The TGA analysed conducted under $100 \mathrm{ml} / \mathrm{min}$ nitrogen gas for a $10^{\circ} \mathrm{C} / \mathrm{min}$ heating rate. The result of the thermal properties analysis on EFB boards were showed in Figure 3. The decomposition occurred at $100.46^{\circ} \mathrm{C}$ (at the first peak) and continued to the second peak at $204.81{ }^{\circ} \mathrm{C}$ and completed at the third peak $\left(380.83^{\circ} \mathrm{C}\right)$. The degradation of UF resin composite boards occurred at $99.93^{\circ} \mathrm{C}$ (at the first peak), continued at $168.45^{\circ} \mathrm{C}$ (second peak) and completed at third peak $\left(389.26^{\circ} \mathrm{C}\right)$. The loss of UF resin in weight recorded high at third peak at $58.48 \%$, followed by the second peak at $9.39 \%$ and the first peak at $8.43 \%$ (see Table 4). The final decomposition of the EFP composite boards is lower than of the UF resin at $389.26^{\circ} \mathrm{C}$ to $380.83^{\circ} \mathrm{C}$. This indicates the presence of

cellulose fibres from the EFB gives influences to significant effect on thermal stability of the EFB boards. Disturbance in the original crystal lattice of the composite by the EFB boards could probably be the results of this occurrence [31].

Table 7: Correlation coefficient between the physical and mechanical properties of EFB composite boards at different density and resin content

\begin{tabular}{|c|c|c|c|c|c|c|c|c|c|c|c|c|c|}
\hline & $\mathrm{D}$ & RCT & MC & DEN & 2HWA & $24 \mathrm{WA}$ & 2HTS & $24 \mathrm{TS}$ & MOR & MOE & IB & SWE & SWF \\
\hline $\mathrm{D}$ & 1 & $0.0000^{\mathrm{ns}}$ & $-0.3279^{*}$ & $0.9656^{* *^{*}}$ & $-0.7247^{* *}$ & $-0.2250^{\text {ns }}$ & $-0.1138^{\text {ns }}$ & $0.0218^{\mathrm{ns}}$ & $0.7689^{* *}$ & $0.8284^{* *}$ & $0.7067^{* *}$ & $0.9204^{* *}$ & $0.8916^{* *}$ \\
\hline RCT & & 1 & $0.4042^{* *}$ & $-0.0031^{\mathrm{ns}}$ & $-0.4934^{* *}$ & $-0.8027^{* *}$ & $-0.7537^{* *}$ & $-0.8245^{* *}$ & $0.3448^{* *}$ & $0.3242^{*}$ & $0.4774^{* *}$ & $0.1720^{\mathrm{ns}}$ & $0.1651^{\mathrm{ns}}$ \\
\hline MC & & & 1 & $-0.2795^{*}$ & $0.2709^{*}$ & $-0.4750^{* *}$ & $-0.3366^{* *}$ & $-0.3441^{* *}$ & $-0.0993^{\text {ns }}$ & $-0.1058^{\mathrm{ns}}$ & $-0.0972^{\mathrm{ns}}$ & $-0.1480^{\mathrm{ns}}$ & $-0.1591^{\mathrm{ns}}$ \\
\hline DEN & & & & 1 & $-0.6945^{* *}$ & $-0.2103^{\text {ns }}$ & $-0.1093^{\text {ns }}$ & $0.0024^{\mathrm{ns}}$ & $0.7693^{* *}$ & $0.8202^{* *}$ & $0.7053^{* *}$ & $0.8984^{* *}$ & $0.8770^{* *}$ \\
\hline 2HWA & & & & & 1 & $0.3625^{* *}$ & $-0.3191^{*}$ & $0.3405^{* *}$ & $-0.7504^{* *}$ & $-0.7425^{* * *}$ & $-0.7800^{* *}$ & $-0.6947^{* * *}$ & $-0.6460^{* * *}$ \\
\hline $24 \mathrm{WA}$ & & & & & & 1 & $0.8353^{* *}$ & $0.7991^{* *}$ & $-0.4359^{* *}$ & $-0.4794^{* *}$ & $-0.5283^{* *}$ & $-0.4073^{* *}$ & $-0.3835^{* *}$ \\
\hline 2HTS & & & & & & & 1 & $0.7980^{* *}$ & $-0.3141^{*}$ & $-0.3625^{* *}$ & $-0.4291^{* *}$ & $-0.3357^{* *}$ & $-0.2814^{*}$ \\
\hline 24TS & & & & & & & & 1 & $-0.3909^{* *}$ & $-0.3767^{* *}$ & $-0.5198^{* *}$ & $-0.1874^{\text {ns }}$ & $-0.1480^{\mathrm{ns}}$ \\
\hline MOR & & & & & & & & & 1 & $0.9754^{* *}$ & $0.8811^{* *}$ & $0.8237^{* *}$ & $0.7641^{* *}$ \\
\hline MOE & & & & & & & & & & 1 & $0.8840^{* *}$ & $0.8912^{* *}$ & $0.8269^{* *}$ \\
\hline IB & & & & & & & & & & & 1 & $0.7711^{* *}$ & $0.7102^{* *}$ \\
\hline SWE & & & & & & & & & & & & 1 & $0.8862^{* *}$ \\
\hline SWF & & & & & & & & & & & & & 1 \\
\hline
\end{tabular}

Note: ${ }^{*}=\mathrm{p} \leq 0.05,{ }^{* *}=\mathrm{p} \leq 0.01,{ }^{\mathrm{ns}}=$ not significant, $\mathrm{RCT}=$ resin content, $\mathrm{MC}=$ moisture content, $\mathrm{DEN}=$ density, $2 \mathrm{HWA}=2$ hours water absorption, $24 \mathrm{WA}=24$ hours water absorption, $2 \mathrm{HTS}=2$ hours thickness swell, $24 \mathrm{TS}=24$ hours thickness swell, $\mathrm{MOR}=$ Modulus of rupture, $\mathrm{MOE}=$ Modulus of elasticity, $\mathrm{IB}=$ Internal bonding, $\mathrm{SWE}=$ Edge screw withdrawal, $\mathrm{SWF}=$ Face screw withdrawal.

The degradation process of the EFB and UF resin boards started by the depolymerisation of the molecular structure and the dehydration of tested boards and later, the slow releases of formaldehyde present in the UF resin [30][32]. The process resumed by the cleave of linkages that occurred in the EFB composite and UF resin. Carbon-hydrogen $(\mathrm{C}-\mathrm{H})$ bonds were broken first, followed by carbon-oxygen (C-O) bonds, carbon-carbon (C-C) bonds, and hydrogenoxygen $(\mathrm{O}-\mathrm{H})$ bonds. This is the stage where the cellulose, hemicellulose, and lignin began to decomposes. The thermal degradation of polymer blocks of biomass occurred at the second peak. Hemicellulose and lignin degraded first [12][4]. These were due to their less rigid molecular structure compared to the cellulose. Upon the introduction of oxygen (3rd peak), combustion occurred, and the final weight loss infers the amount of carbon in the composite. Table 8 showed the carbon contents of the boards at $58.48 \%$ (UF resin boards) and $66.65 \%$ (EFB composite boards). 
Composite Boards Properties from Elais guineensis Empty Fruit Bunch

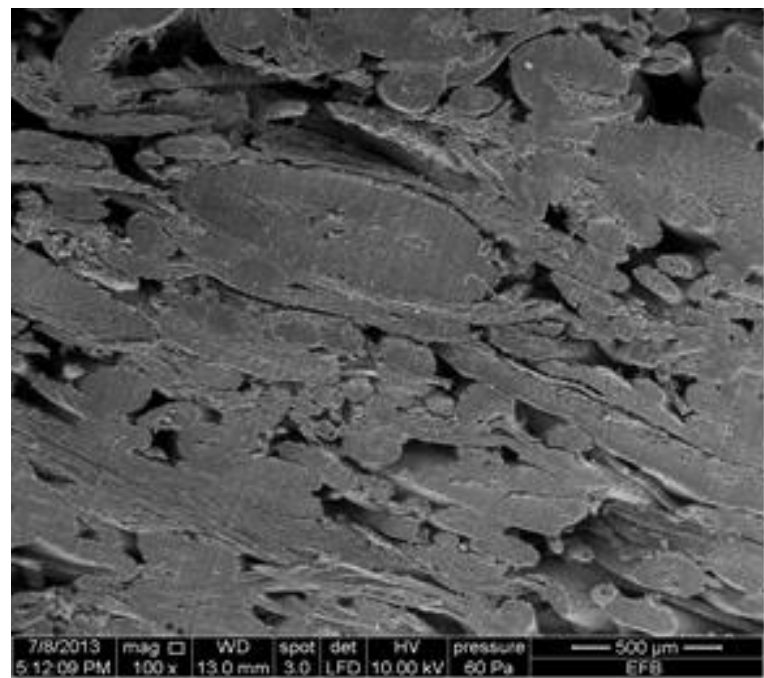

Figure 1: The $\mathrm{x}$-section of the $500 \mathrm{~kg} / \mathrm{m}^{3} \mathrm{EFB}$ composite boards with resin content $10 \%$

(Magnification at 100x)

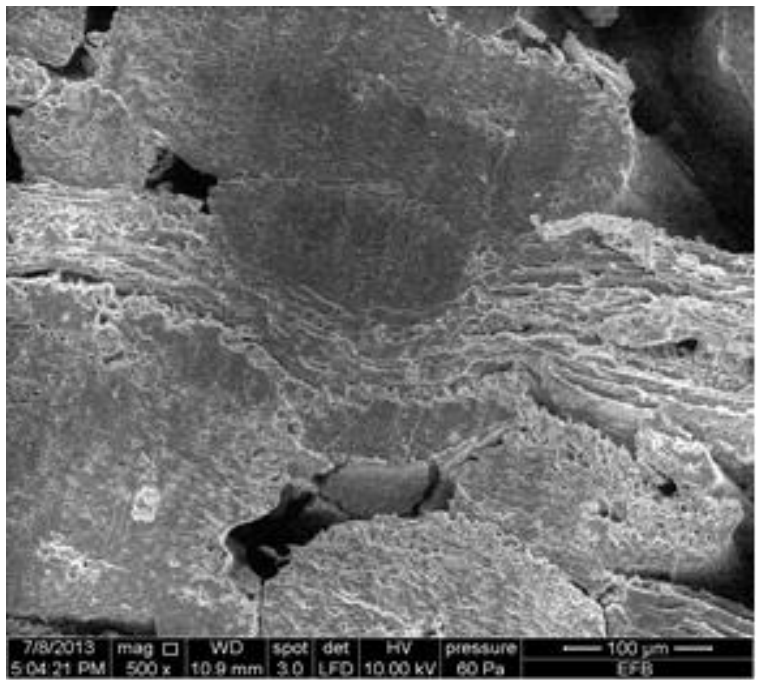

Figure 2: The $\mathrm{x}$-section of $500 \mathrm{~kg} / \mathrm{m} 3 \mathrm{EFB}$ composite boards with resin content $10 \%$

(Maginfication at 500x)

Table 8: Thermogravimetric analysis (TGA) weight loss (\%) with temperature for UF resin and EFB composite boards

\begin{tabular}{llrrr}
\hline & & First peak & Second peak & Third peak \\
\hline EFB boards & Temperature $\left({ }^{\circ} \mathrm{C}\right)$ & 100.46 & 204.81 & 380.83 \\
& Weight loss $(\%)$ & 9.12 & 11.14 & 66.65 \\
\hline UF resin boards & Temperature $\left({ }^{\circ} \mathrm{C}\right)$ & 99.93 & 168.45 & 389.26 \\
& Weight loss $(\%)$ & 8.43 & 9.39 & 58.48 \\
\hline
\end{tabular}

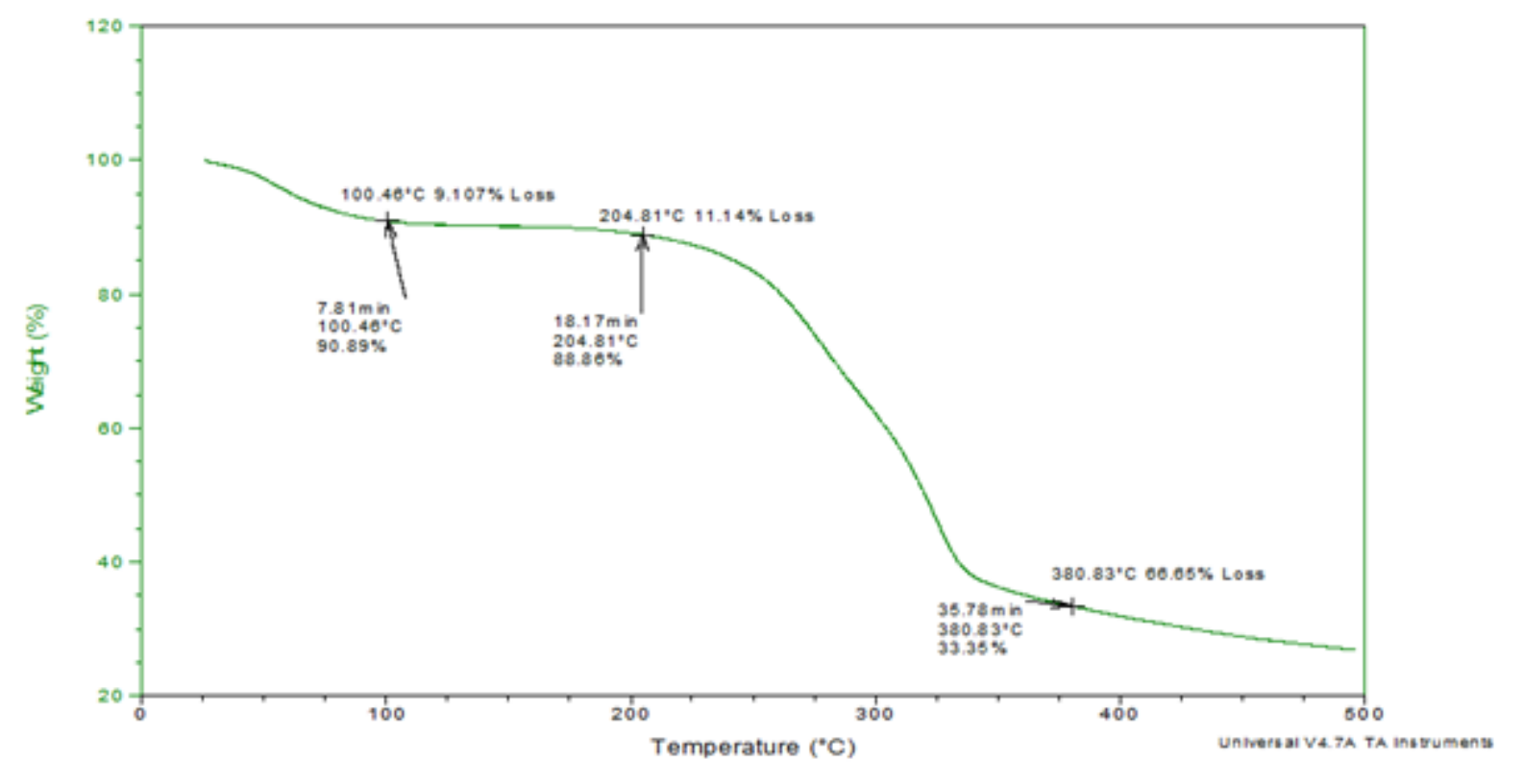

Figure 3: TGA properties of EFB composite boards. 
Composite Boards Properties from Elais guineensis Empty Fruit Bunch

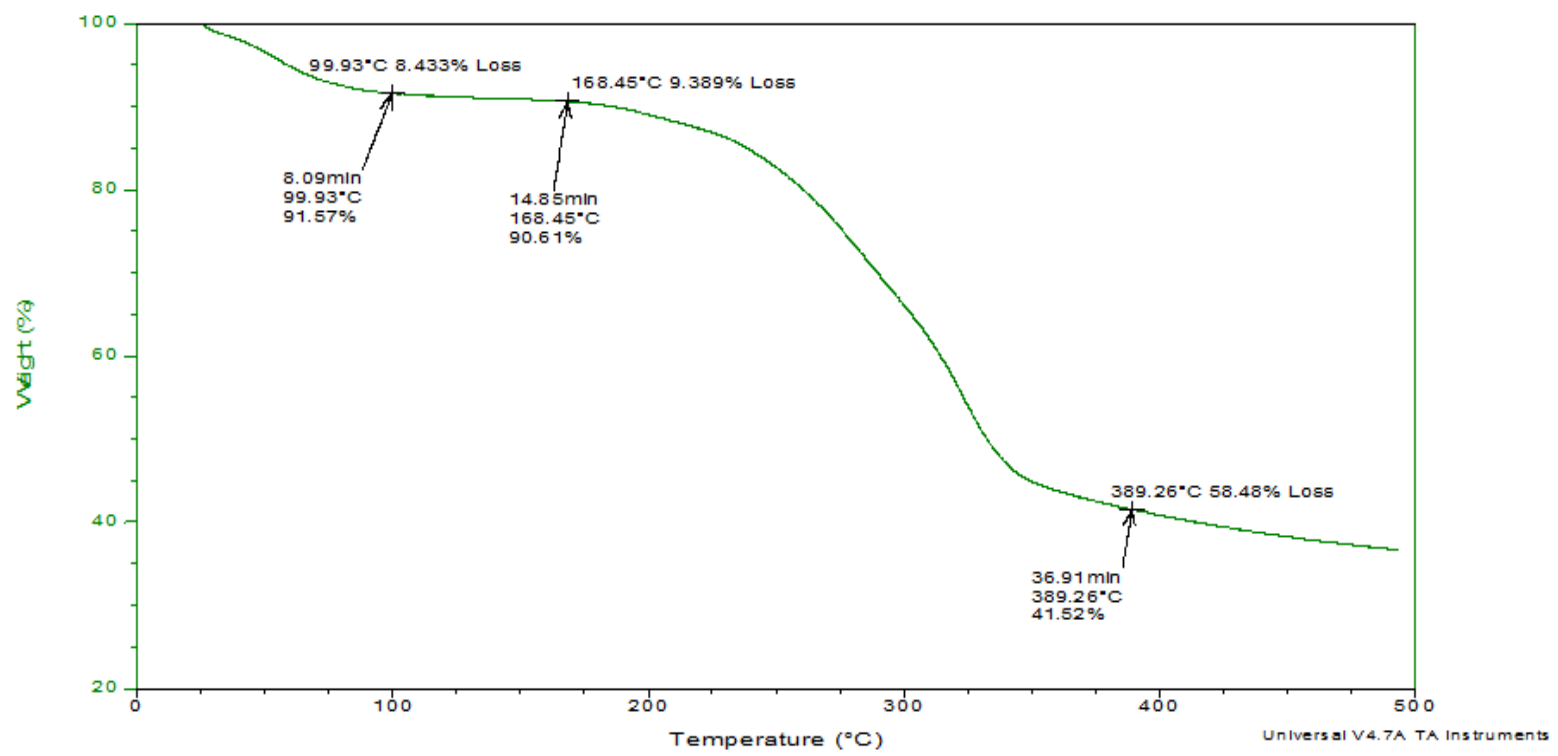

Figure 4: TGA properties of EFB composite boards with UF resin.

\section{CONCLUSION}

The properties of the EFB composites boards met the specification for the commercial usage. The density influenced the boards overall performances and the amount of resin used. The EFB composite boards produced at $700 \mathrm{~kg} / \mathrm{m}^{3}$ density with $14 \%$ resin possessed showed excellent properties and stable dimensional stability.

The EFB composite boards produced with UF resin possessed an overall excellent thermal stability analyzed with thermogravimetric.

\section{ACKNOWLEDGMENT}

This work supported by the UCTS Research Grant UCTS/RESEARCH/4/2017/01. We would also like to express our gratitude to Universiti Malaysia Kelantan (UMK) and Forest Research Institute Malaysia (FRIM) for their cooperation in allowing us to conducts parts of the study in their campuses.

\section{REFERENCES}

[1] Rowell, R. M. (2005). Handbook of Wood Chemistry and Wood Composites. CRC Press.

[2] Razak, W, HW Samsi, A Mohamad, O Sulaiman, R Salim (2008). Properties of laminated veneer lumber from oil palm trunks. Journal of Plant Sciences 3 (4), 255-259.

[3] Abdullah, N. \& Bridgwater, A. V. (2006). Pyrolysis liquid derived from oil palm empty fruit bunches. Journal of Physical Science, 17(2), 117129.

[4] Abdul Khalil, H. P. S., Siti Alwani, M. \& Mohd. Omar, A. K. (2006). Cell walls of tropical fibers. Journal of Biology Resources, 1(2), 220-232.

[5] European standard EN 310 (1993). "Wood-based panels; Determination of modulus of elasticity in bending and of bending strength," European Committee for Standardization, Brussels, Belgium.

[6] European standard EN 322 (1993). "Wood-based panels; Determination of moisture content," European Committee for Standardization, Brussels, Belgium.

[7] European standard EN 323 (1993). "Wood-based panels; Determination of density," European Committee for Standardization, Brussels, Belgium.

[8] European standard EN 317 (1993). "Particleboard and fiberboards; Determination of swelling in thickness after immersion in water," European Committee for Standardization, Brussels, Belgium.

[9] EN 325 (2012). Wood-based panels: Determination of dimensions of test pieces. European Committee for Standardization, Brussels- Belgium.

[10] European standard EN 319 (1993). "Particleboard and fiberboards; Determination of tensile strength perpendicular to the plane of the board," European Committee for Standardization, Brussels, Belgium.

[11]BS 5669 (1989). Particleboard. Methods of sampling, conditioning and test. British Standards Institution.

[12] Rosnah, M.S., Hasamudin, W.W.H., Gapor, A.M.T \& Kamarudin, H. (2006). Thermal properties of oil 
palm fibre, celluose and its derivatives. Journal of Oil Palm Research. 18, 272-277.

[13] Yong, J. W., Silikas, N., Zhang, Z. T. \& Watts, D. C. (2011). Hygroscopic dimensional changes of self-adhering and new resin-matrix composite water sorption/desorption cycles. Journal of Dental Materials, 27(3), 259-266.

[14] Loh, Y. W., H’ng, P. S., Lee, S. H., Lum, W. C. \& Tan, C. K. (2010). Properties of particleboard produced from admixture of rubberwood and Mahang species. Asian Journal of Applied Science. ISSN 1996-3343, 1-5.

[15] Wong, E. D., Zhang, M., Wang, Q. \& Kawai, S. (1999). Formation of the density profile and its effects on the properties of particleboard. Wood Science Technology, 33(4), 327-340.

[16] Guler, C. \& Buyuksari, U. (2011). Effect of production parameter on the physical and mechanical properties of particleboards made from peanut (Arachis hypogaea L.) hull. BioResources, 6(4), 5027-5036.

[17] Garay, R. M., MacDonald, F., Acevedo, M. L.,Calderon, Beatriz., Araya, J. E. (2009). Particleboard made with crop residues mixed with wood from Pinus radiata. Journal of Bioresources. 4(4), 1396-1408.

[18]Zheng, L., Pan, Z., Zhang, R., Jenkins, B. M. \& Blunk, S. (2005). Proceedings from '05 ASAE Annual International Meeting: Medium-density particleboard from saline jose tall wheatgrass. Florida.

[19] Izyan, K., R Wahab, M Sudin, O Sulaiman, A Hassan, RH Alamjuri (2010). Chemical Changes in 15-Year-old Cultivated Acacia Hybrid Oil-Heat Treated at 180,200 and $220^{\circ} \mathrm{C}$. International Journal of Chemistry 2 (1).

[20] Jacobs, J. A. \& Kliduff, T. F. (1994). Engineering material technology: Structure, processing, properties, and selection. (2nd ed.). Upper Saddle River, NJ: Prentice Hall Inc.

[21] European standard EN 312-3. 1996. ParticleboardsSpecifications-Part 3: Requirements for boards for interior fitments (including furniture) for use in dry conditions. European Standardization Committee, Brussels

[22] Paridah, M. T., Saifulazry, S. O. A., Jalaludin, H., Zaidon, A. \& Rahim, S. (2010). Mechanical and physical properties of particleboard made from 4year-old rubberwood of RRIM 2000 series clones.
Journal of Tropical Forest Sciences. 22(4), 440447.

[23] Yang, H. S., Kim, D. J. \& Kim, H. J. (2003). Rice straw-wood particle composite for sound absorbing wooden construction materials. Bioresource Technology, 86, 117-121.

[24] Sukhairi, M. R., R. Wahab, O. Sulaiman, Othman, J. Moktar, A. \& Mohamed, T.A. (2011). Properties of composite boards from oil palm frond agricultural waste. BioResources 6 (4), 4389-4403.

[25] Ashori, A. \& Nourbaksh, A. (2008). Effect of press cycle time and resin content on physical and mechanical properties of particleboard panels made from the underutilized low-quality raw materials. Industrial Crops Production, 28, 225-230.

[26] Gupta, G., Yan, N. \& Feng, M. W. (2011). Effects of pressing temperature and particle size on bark board properties made from beetle-infested lodgepole pine (Pinus contorta) barks. Forest Products Journal. 61(6), 478-488.

[27] Papadopolous, A. N. (2006). Property comparisons and bonding efficiency of UF and PMDI bonded particleboards as affected by key process variables. BioResources. 1(2), 201-208.

[28] Moslemi, A. (1974). Particleboard. Volume 1: Materials. Carbondale, Illionis: Southern Illionis University Press.

[29] Hnin, Y. W., Sandar, T. \& Kyau, M. N. (2011). Perticleboard derived from rattan fiber waste. Universities Research Journal, 4(3), 323-334.

[30] Marashdeh, M. W., Rokiah, H., Aziz, A. T., Bauk, S. \& Othman, S. (2011). Effect of particle size on the characterization of binderless particleboard made from Rhizophora spp. mangrove wood for use as phantom material. BioResources, 6(4), 4028-4022.

[31] Singha, A.S., \& Thakur, V.K. (2009). Study of mechanical properties of urea-formaldehyde thermosets reinforced by Pine Needle Powder. BioResources 4(1), 292-308.

[32]Zorba, T., Papadopoulo, A., Hatjiissaak, Paraskevopoulos, K. M. \& Chrissafis, K. (2008). Urea-formaldehyde resins characterized by thermal analysis and FTIR method. Journal of Thermal Analysis and Calorimetry, 92(1), 29-33. 